\title{
MAGAS ANTOCIÁN TARTALMÚ BÚZA GENOTÍPUSOK REOLÓGIAI JELLEMZÉSE
}

\author{
Ács Erika - Kovács Zsuzsa - Ács Katalin - Langó Bernadett - Szabóné Czank \\ Bernadett - Cseuz László - Matuz János
}

\begin{abstract}
Absztrakt: A gabonafélék fogyasztása meghatározó az egészségünk megőrzése, javítása szempontjából. A Gabonakutató gazdag genetikai háttérrel, nagy nemesítői tapasztalattal évtizedek óta foglalkozik speciális igények kielégítésére is alkalmas növényfajták előállításával. Az elmúlt másfél évtized nemesítöi tevékenységének eredményeként, hazánkban elsőként került sor magas antocián tartalmú búza genotípusok nemesítésére. Jelen kísérletünk célja, hogy 2 kék és 3 bibor búza genotípus humán felhasználás szempontjából meghatározó reológiai jellemzőit megismerjük, ill. a felhasználási területnek megfelelö genotípusok kiválasztásához ismereteket szerezzünk. A 3 éves kísérlet eredményei alapján a fehér liszteknek nagyrészt igen kiválóak a reológiai tulajdonságai. A teljes kiörlésü lisztek minősítésekor nagyobb genotípus és évjárathatást tapasztaltunk, a reológiai jellemzök általános gyengülése mellett. Találtunk önálló gépi feldolgozásra is alkalmas, ill. csak keverékekben történő alkalmazásra ajánlható genotípusokat. A teljes kiőrlésü lisztekböl készült próbacipók térfogata mintegy 30-35\%-kal kisebb volt a fehér lisztek cipóinál.
\end{abstract}

Abstract: Cereals play important role to maintain and improve our health. Cereal Research Ltd. has a rich genetic background and wide breeding experience to satisfy special needs by developing applicable cereal varieties. The breeding efforts in the last fifteen years resulted the first wheat genotypes in Hungary, with high anthocyanin content. In this experiment the rheological values of 2 blue and 3 purple wheat genotypes were investigated to predict the end-use quality for human utilization and select genotypes for different end-use purposes. According to the results of our 3 yearlong experiment, we can tell that white flours of these genotypes have mostly excellent rheological traits. The effects of the genotype and crop year were higher when whole-meal flour were evaluated, and these flours showed weaker rheological values as well. We have found genotypes which are suitable for industrial use as per se, and genotypes also recommended for use in flour blends. Volume of breads made with whole-meal flour was $30-35 \%$ smaller than white flour breads.

Kulcsszavak: bíbor búza, kék búza, sütési minőség, reológia

Keywords: purple wheat, blue wheat, baking quality, rheology

\section{Bevezetés}

A gabonafélék az emberiség legfontosabb táplálékforrásai. Fogyasztásuk meghatározó az egészségünk megőrzése, javítása szempontjából. A fejlett és fejlődő országok, köztük hazánk növénytermesztésében a termésátlagok növelése mellett egyértelmúen fontossá vált a felhasználói igényeknek megfelelö, differenciált minőségü növényi termékek előállítása, segítségükkel az egészségmegörzést szolgáló, változatos élelmiszer termékek létrehozása.

A Gabonakutató gazdag genetikai háttérrel, nagy nemesítöi tapasztalattal évtizedek óta foglalkozik speciális igények kielégítésére is alkalmas növényfajták előállításával, így színes búza genotípusok létrehozásával.

A bíbor és kék búzafajták vad és nemesített fajtái a világ több területén (ÉszakAfrika, Új-Zéland, Kína, USA, Ausztria) jól ismertek. Magas antocianin és egyéb hasznos beltartalmi komponensei antioxidáns, antibakteriális hatásúak (EscribanoBailon et al., 2004). A bíbor genotípusok antocián tartalma a maghéjban, a kék 
genotípusoké a szem aleuron rétegében található (Zeven, 1991). Ennek megfelelően az antocián tartalom megörzése a teljes örlemény felhasználásával valósul meg legjobban. Az antocián mennyisége a kék genotípusokban lényegesen magasabb (Varga et al., 2013).

A bíbor búza széles körü sütőipari célú bevezetése 2006-ban indult. Ma már mintegy 40 országban alkalmazzák pékipari termékek komponenseként (Iba, 2006). $\mathrm{Az}$ elmúlt másfél évtizedben a Gabonakutató nemesítői tevékenységének eredményeként, hazánkban elsőként került sor magas antocián tartalmú bíbor és kék búza genotípusok nemesítésére.

A szakirodalomból láthatjuk (Martinek et al., 2013), hogy a köztermesztésben lévő európai színes fajták reológiai jellemzői eltérhetnek az általánosan megfogalmazott sütőipari igényektől. Ezért jelen kísérletünk célja, hogy a saját nemesítésű, agronómiailag megfelelő színes genotípusok humán felhasználás szempontjából meghatározó reológiai jellemzőit megismerjük, ill. a felhasználási területnek megfelelő genotípusok kiválasztásához ismeretekkel rendelkezzünk.

\section{Anyag és módszer}

A vizsgálathoz 2 kék (Kék1-GK Békés/SB1; Kék2 - GK Ati/SB1) és 3 bíbor (Bíborl - Konini/Capo; Bíbor2 - Laval19/Konini; Bíbor3 - Charcoal/Zabava Odeszkaja/GK Élet) genotípust alkalmaztunk, melyeket 2015-2017 között a Gabonakutató Nonprofit Kft. Kecskés István telepén (46.2379869; 20.105924) termesztettük. A szemtermésekből PERTEN SKCS 3100 készülékkel AACC 55-31 szerint (AACC, 1995) szemkeménységi értéket mértünk. Brabender Senior labormalmon fehér lisztet, Perten 3100 kalapácsos darálón $(0,8 \mathrm{~mm}$-es performációt alkalmazva) teljes kiörlésü lisztet állítottunk elö. Vizsgáltuk a fehér lisztek nedves sikér mennyiségét (MSZ EN ISO 21415-1), ill. a Zeleny szedimentációs indexet (MSZ EN ISO 5529). Meghatároztuk a reológiai tulajdonságokat Brabender Farinográffal (MSZ EN ISO 5530-1) fehér lisztből mindhárom évben, teljes kiőrlésü lisztből két évben $(2015,2016)$. A minőségi osztályba sorolás a magyar minőségi értékszám (MÉSZ) alapján az MSZ 6369-6, ill. az MSZ 6383:2017 szerint történt. A kétféle liszttípusból cipóvizsgálatot is végeztïnk (MSZ 6369-8:1988). Az adatok elemzésére kéttényezős varianciaanalízist használtunk (Sváb, 1973). Az átlagok páronkénti összehasonlításához Fisher-féle post-hoc analízist alkalmaztunk.

\section{Eredmények és értékelésük}

\subsection{Szemkeménységi értékek (1/a. táblázat)}

A genotípusok három év átlagában 49 és 77 közötti értéket mutattak, jellemzöen - a Bíborl kivételével - kemény szemszerkezetüek voltak. A legkeményebb szemszerkezettel a Kék2 genotípus rendelkezik. Mindhárom vizsgált évben ez a genotípus mutatta a legmagasabb szemkeménységi értéket. A fajtaátlagok és évjárat átlagok között szignifikáns különbségek mutatkoztak. A 2016-os év eredményezte a legalacsonyabb (59), a 2017-es év a legmagasabb (78) szemkeménységi érték átlagot. 


\subsection{Zeleny szedimentációs index (l/a. tâblázat)}

A Zeleny szedimentációs indexek is jellemzően megfelelő malmi minőséget jeleztek 32 és $51 \mathrm{ml}$ közötti fajtaátlaggal. A Bíbor 3 genotípus volt mindhárom vizsgált évben a legnagyobb szedimentációs értékü. A fajtaátlagok mellett az évjárat átlagok között is szignifikáns különbségeket találtunk. A 2016-os év eredményezte a legnagyobb (43 ml), a 2017-es év a legkisebb (37 ml) szedimentációs indexet.

\subsection{Nedves sikértartalom (1/a. táblázat)}

A nedves sikér vizsgálatok eredményeként megfigyelhető, hogy a Bíborl és Bíbor2 genotípusok kisebb sikértartalommal rendelkeznek $(27,4 \% ; 26,6 \%)$, míg a Bíbor3 genotípus mindhárom évben a legnagyobb sikértartalmakat hozta $(36,8 \% ; 41,8 \%$; $32,1 \%$ ). Az évek átlagai szignifikánsan különböztek egymástól, a legkedvezöbb nedves sikér értékeket 33,6\%-os átlaggal 2016-ban, a legalacsonyabbakat 27,6\%-os átlaggal 2017-ben mértük.

\section{1/a. táblázat: A színes búza genotípusok minőségi jellemzői (2015-2017) I.}

\begin{tabular}{|c|c|c|c|c|c|c|c|c|c|c|c|c|}
\hline & \multicolumn{4}{|c|}{ Szemkeménységi érték . } & \multicolumn{4}{|c|}{ Zeleny szedimentációs index ml } & \multicolumn{4}{|c|}{ Nedves sikér \% } \\
\hline Genotipus & 2015 & 2016 & 2017 & Átlag & 2015 & 2016 & 2017 & Átlag & 2015 & 2016 & 2017 & Atlag \\
\hline Kék 1 & 71 & 63 & 82 & $72^{c}$ & 42 & 34 & 39 & $38^{\mathrm{ab}}$ & 34,7 & 33,4 & 29,1 & $32,4^{b}$ \\
\hline Kék2 & 76 & 68 & 88 & $77^{0}$ & 41 & 49 & 36 & $42^{b}$ & 32,5 & 33,3 & 26,5 & $30,8^{6}$ \\
\hline Bibort & 45 & 43 & 60 & $49^{\circ}$ & 32 & 35 & 29 & $32^{2}$ & 26,7 & 31,6 & 23,9 & $27,4^{4}$ \\
\hline Bibor2 & 66 & 63 & 84 & $71^{\mathrm{BC}}$ & 33 & 40 & 38 & $37^{\mathrm{ab}}$ & 25,2 & 28,0 & 26,4 & $26,6^{\circ}$ \\
\hline Bibor3 & 69 & 57 & 78 & $68^{b}$ & 53 & 58 & 41 & $51^{c}$ & 36,8 & 41,8 & 32,1 & $36,9^{c}$ \\
\hline Átlog & $65^{b}$ & $59^{3}$ & $78^{c}$ & & $40^{\mathrm{ab}}$ & $43^{b}$ & $37^{a}$ & & $31,2^{5}$ & $33,6^{c}$ & $27,6^{6}$ & \\
\hline S2D5\% & \multicolumn{2}{|c|}{ bármely kettơ kōzt } & & 5,34 & & & & 11,73 & & & & 4,81 \\
\hline & \multicolumn{2}{|c|}{ fajtaátlagok közt } & & 3,08 & & & & 6,77 & & & & 2,77 \\
\hline & \multicolumn{2}{|c|}{ évátlagok közt } & & 2,39 & & & & 5,24 & & & & 2,15 \\
\hline
\end{tabular}

$\mathrm{Az}$ azonos oszlopban, ill. azonos sorban szereplö, eltérỏ betükkel jelzett átlagértékek egymástól $P=0,05$ szinten szignifikánsan különböznek.

\subsection{Farinográfos értékszámok alakulása (1/b. táblázat)}

Farinográfos értékszámok alapján - a korai minőségi szelekciónak is köszönhetöen - nem volt ritka a prémium minőségi besorolású $(A)$ genotípus. A fehér lisztek három éves átlagai 70 felettiek voltak, kivéve a Bíborl genotípust $(64,8)$, de ez is megfelelően jó malmi minőséget mutatott. A Bíbor2 reológiai tulajdonságai a 85,2 (A1) farinográfos értékszám átlaggal kiemelkedőnek bizonyult.

A teljes kiőrlésü lisztekből végzett vizsgálatok eredményei 20 farinográfos értéknyi, ill. 1-2 kategória csökkenést mutattak a fehér lisztek értékeihez képest. A fehér lisztek vizsgálatánál mért $B 2$, és némely esetben már a $B 1$ farinográfos besorolású genotípusok teljes kiőrlésủ lisztjei $C$ (45 alatti) kategóriásak lettek.

$\mathrm{Az}$ évjáratokban szignifikáns különbségeket kaptunk, 2015 bizonyult a gyengébbnek. A két éves adatsor alapján reológiai szempontból a Kék2 és a Bíbor 2 genotípusok teljes kiőrlésü lisztjei legalább $B$ besorolásúak voltak, ami azt mutatja, hogy ezek az anyagok önállóan is alkalmazhatók pékipari termékekhez. 


\subsection{Cipótérfogatok (1/b. táblázat)}

A genotípusok fehér lisztjeinek cipótérfogata a három éves átlagban 913 és $1059 \mathrm{~cm}^{3}$ közötti volt, szignifikáns különbségek nélkül. Magas arányban találtunk $1000 \mathrm{~cm}^{3}$ feletti mintákat. Az évjárathatás szignifikánsnak bizonyult, 2016-ban mértünk magasabb értékeket $1087 \mathrm{~cm}^{3}$-es évátlaggal, míg 2015-ben $918 \mathrm{~cm}^{3}$ volt ugyanez az érték.

A genotípusok teljes kiőrlésű lisztjeiből készült próbacipó-térfogatok mintegy 30-35\%-kal kisebbek voltak a fehér lisztek cipóinál, átlagosan $704-769 \mathrm{~cm}^{3}$ térfogatokat mértünk. A fajtaátlagok szignifikánsak voltak, a Kék2 és a Bíborl genotípusok adták a nagyobb cipótérfogatokat $\left(769\right.$ és $\left.755 \mathrm{~cm}^{3}\right)$.

A fehér és teljes kiőrlésü lisztekből készült cipók az 1 . ábrán láthatók.

1/b. táblázat: A színes búza genotípusok minőségi jellemzői (2015-2017) II.

\begin{tabular}{|c|c|c|c|c|c|c|c|c|c|c|c|c|c|c|c|}
\hline & \multicolumn{8}{|c|}{ Fehér líszt } & \multicolumn{7}{|c|}{ Teljes kiỡlésú liszt } \\
\hline & \multicolumn{4}{|c|}{ Farinográtos érték - } & & \multicolumn{3}{|c|}{ Cipotértogat $\mathrm{cm}^{3}$} & \multicolumn{3}{|c|}{ Faninográfos érték - } & & \multicolumn{3}{|c|}{ Cipotértogat $\mathrm{cm}^{3}$} \\
\hline Genotipus & 2015 & 2016 & 2017 & Atlog & Besorolás & 2015 & 2016 & Atlag & 2015 & 2016 & Átlog & Besorolas & 2015 & 2016 & Attlog \\
\hline Kék1 & 65,2 & 76,4 & 84,9 & $75,6^{\text {ab }}$ & A2 & 945 & 1059 & 1002 & 41,3 & 59,9 & $50,6^{6}$ & B2 & 670 & 756 & $713^{4}$ \\
\hline Kék2 2 & 74,7 & 93,0 & 64,2 & $77,3^{\text {ab }}$ & A2 & 849 & 977 & 913 & 55,9 & 71,0 & $63,5^{b}$ & $B 1$ & 737 & 801 & $769^{b}$ \\
\hline Bibort & 53,6 & 68,2 & 72,5 & $64,8^{\circ}$ & $B 1$ & 971 & 1146 & 1059 & 41,0 & 50,3 & $45,7^{\circ}$ & 82 & 724 & 785 & $755^{b}$ \\
\hline Bibor2 & 55,7 & 100,0 & 100,0 & $85,2^{b}$ & A1 & 1021 & 1042 & 1032 & 52,5 & 71,3 & $61,9^{6}$ & B1 & 673 & 736 & $704^{4}$ \\
\hline Bibor3 & 68,5 & 81,5 & 76,7 & $75,6^{\text {ab }}$ & A2 & 805 & 1210 & 1008 & 42,1 & 53,8 & $48,0^{2}$ & $B 2$ & 702 & 722 & $712^{4}$ \\
\hline Átlog & $63,5^{+1}$ & $83,8^{6}$ & $79,7^{0}$ & & & $918^{8}$ & $1087^{\circ}$ & & $46,6^{6}$ & $61,3^{b}$ & & & $701^{11}$ & $760^{\circ}$ & \\
\hline S205\% & \multicolumn{2}{|c|}{ bármely kettó kōzt } & & 26,64 & & & & 282,2 & & & 8,24 & & & & 46,9 \\
\hline & \multicolumn{2}{|c|}{ fajtaótlagok közt } & & 15,38 & & & & 199,5 & & & 5,83 & & & & 33,2 \\
\hline & \multicolumn{2}{|c|}{ évátlagok kōzt } & & 11,91 & & & & 126,2 & & & 3,69 & & & & 21,0 \\
\hline
\end{tabular}

Az azonos oszlopban, ill. azonos sorban szereplő, eltérỏ betükkel jelzett átlagértékek egymástól $P=0,05$ szinten szignifikánsan különböznek.

\section{Következtetések}

Jelen tanulmány összegzéseként megállapítható, hogy a szegedi Gabonakutató által nemesített magas antocián tartalmú kék és bíbor búza genotípusok sütőipari szempontból fontos reológiai tulajdonságai - a tudatos, minőség-centrikus nemesítés eredményeként - nem maradnak el a hagyományos kenyérbúzákétól. A genotípusok között szignifikáns különbségek tapasztalhatók, évjárati determináltsággal. A fehér lisztek minden esetben jól, ill. igen jól használhatók gépi feldolgozásra. A táplálkozásélettanilag jelentős teljes kiőrlésủ lisztek feldolgozásánál a gyengébb reológiai tulajdonságok miatt fontos a megfelelő genotípus kiválasztása, esetleg keverékek képzése, valamint szóba jöhet a teljes kiőrlésü lisztek helyett a közel teljes kiőrlésủ céllisztek létrehozása az őrlési jellemzők célzott megválasztásával. 
1. ábra: Próbacipók fehér és teljes kiőrlésủ lisztekből (2016)

Kék1

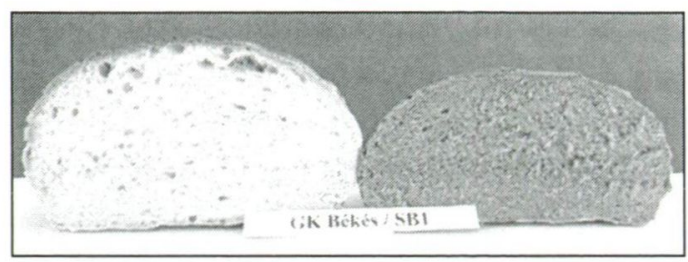

Kék2

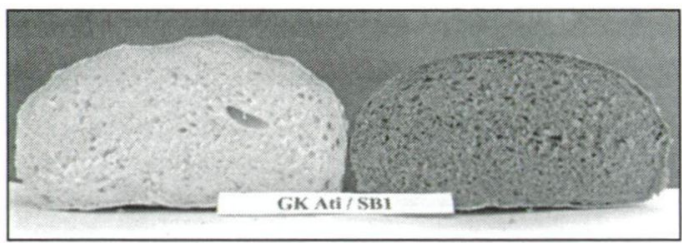

Bíbor1

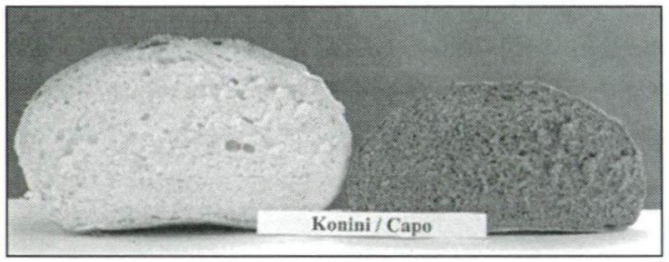

Bíbor2

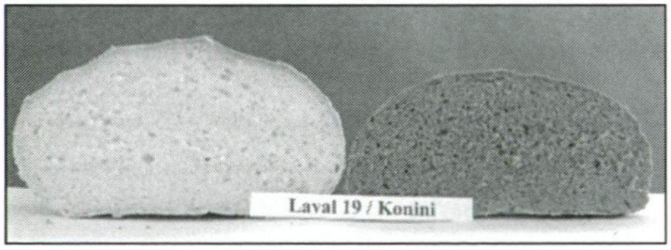

Bíbor3

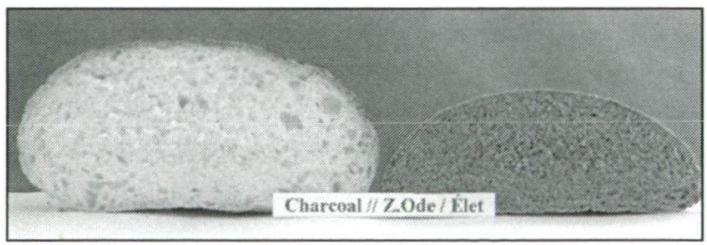

\section{Köszönetnyilvánítás}

A munkát a GINOP-2.2.1-15-2016-00026 pályázat támogatta, melyet ezúton is köszönnek a szerzők. 


\section{Irodalomjegyzék}

AACC 55-31. (1995): Single-kernel characterisation system for wheat kernel texture. Approved Methods of the AACC. 9.

Escribano-Bailón, M. T., Santos-Buelga, C., Rivas-Gonzalo J. C. (2004): Anthocyanins in cereals. J. Chromat., 1054 (1-2): 129-141.

Iba (2006): <http://www.backaldrin.com/Content.Node/int/brands/more-purpur.en.php>. (2017.09.03.)

Martinek P., Skorpík M., Chrpová J., Fucik P., Schweiger J. (2013): Development of the new winter wheat variety Skorpion with blue grain. Czech J. Genet. Plant Breed., 49 (2): 90-94.

MSZ 6369-6. Lisztvizsgálati módszerek. 6. rész: A tészták fizikai tulajdonságai. A magyar minőségi értékszám (MÉSZ) meghatározása és értékelése.

MSZ 6369-8:1988. Lisztvizsgálati módszerek. Sütéspróba.

MSZ 6383:2017 Búza és durumbúza élelmezési célra.

MSZ EN ISO 21415-1. Búza és búzaliszt. Sikértartalom. 1. rész: A nedves sikér meghatározása kézi módszerrel.

MSZ EN ISO 5529. Búza. A szedimentációs index meghatározása. Zeleny-teszt.

MSZ EN ISO 5530-1. Búzaliszt. A tészta fizikai jellemzői. 1. rész: A vízfelvevő képesség és a reológiai tulajdonságok meghatározása farinográffal.

Sváb J. (1973): Biometriai módszerek a kutatásban. Mezögazdasági Kiadó, Budapest.

Varga M., Bánhidy J., Cseuz L., Matuz J. (2013): The Anthocyanin Content of Blue and Purple Coloured Wheat Cultivars and their Hybrid Generations. Cereal Research Communications. 41 (2): 284-292.

Zeven, A. C. (1991): Wheats with purple and blue grains: a review. Euphytica. 56 (3):143-158. 